\title{
The inhibitory effect of chlorogenic acid on lipid oxidation of grass carp (Ctenopharyngodon idellus) during chilled storage
}

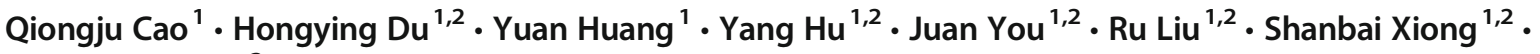 \\ Anne Manyande ${ }^{3}$
}

Received: 12 August 2019 / Accepted: 15 October 2019

(C) Springer Science+Business Media, LLC, part of Springer Nature 2019

\begin{abstract}
Grass carp (Ctenopharyngodon idellus) is a kind of freshwater fish which is rich in polyunsaturated fatty acids and easily exposed to lipid oxidation during refrigeration. The effect of chlorogenic acid (CGA) on lipid oxidation, protein oxidation, enzymatic activities, and color stability of grass carp muscle during chilled storage was investigated. The lipid oxidation was inhibited by CGA, as evidenced by lower thiobarbituric acid values, peroxide values, carbonyl valence, less free fatty acid content, and higher amount of unsaturated fatty acid compared to the control group. CGA also had a positive effect on the whiteness value and the stability of protein oxidation of fish samples. In addition, the inhibitory study of CGA on endogenous lipase and lipoxygenase activities of fish muscle can help to partly illustrate the mechanism that retains its freshness effect. The results indicate that CGA is a novel natural additive which can be used to inhibit lipid and protein oxidation and be applied in the storage of aquatic products or some similar fields.
\end{abstract}

Keywords Chlorogenic acid $\cdot$ Grass carp $\cdot$ Chilled storage $\cdot$ Lipid oxidation

\section{Introduction}

Grass carp (Ctenopharyngodon idellus) is a species of freshwater fish with the highest annual yield in the world. It is preferred by most consumers due to its delicious taste, rich nutrition, and moderate price. Chilled storage is an efficient and popular preservation method during fish transportation and processing. Usually, the activity of some endogenous enzymes and the growth of spoilage microorganisms in fish muscle tissue are effectively inhibited at low temperatures (Babakhani et al. 2015). However, grass carp is rich in protein and polyunsaturated fatty acids such as eicosapentaenoic acid (EPA) and docosahexaenoic acid (DHA), which are easily exposed to oxidation. Oxidative changes (lipid and protein

Hongying Du

hydu@mail.hzau.edu.cn

1 College of Food Science and Technology, Huazhong Agricultural University, Wuhan 430070, Hubei, People's Republic of China

2 National R \& D Branch Center for Conventional Freshwater Fish Processing, Wuhan 430070, Hubei, People's Republic of China

3 School of Human and Social Sciences, University of West London, TW89GA, Middlesex, UK oxidation) are key factors affecting the deterioration in quality of freshwater fish. Oxidizing reactions in fish tissue lead to rancid flavors, discoloration, toxic components, loss of nutrients, and shelf life reduction (Chauhan et al. 2018). Meanwhile, other oxidative products such as free radicals can destroy the cells and macromolecules of the organism (Cerutti 1985). Therefore, in order to maximize utilization of grass carp resources, it is very important to develop efficient approaches to reduce lipid and protein oxidation. The addition of antioxidants is a valid method to prevent lipid and protein oxidation. The possible carcinogenesis and mutagenicity of synthetic antioxidants, such as tert-butyl hydroquinone (TBHQ) and butylated hydroxyl toluene (BHT), have been reported, which have recently made natural antioxidants become popular. Polyphenols are one of the representative natural antioxidants applied widely in the inhibition of protein and lipid oxidation due to their high antioxidant capacity (Farvin and Surendraraj, 2019, Turguta, et al., 2017, Sun, et al., 2019). Chitosan films with grape (Vitis vinifera) seed extract, which contain high amounts of catechin, epicatechin, and phenolic acid, evidently increased the shelf-life of refrigerated salmon (Oncorhynchus) (Alves et al. 2018). Icing with rosemary (Rosmaricus officinalis) extract improved the sensory score and decreased biogenic amine content of sardines 
(Sardinella aurita) (Özyurt et al. 2012). Icing medium containing red alga (Gracilaria verrucosa) extract, which is rich in quercetin-7-methyl ether, delayed the development of chemical parameters of Indian mackerel (Rastrelliger kanagurta) deterioration (Abimannan et al. 2018). Tea polyphenols are natural polyphenols extracted from green tea (Camellia sinensis) leaves and were shown to be effective quality-preservation material for aquatic products (Nie et al. 2018; Ju et al. 2018; Feng et al. 2017).

Chlorogenic acid (CGA) is a kind of polyphenol which is widely present in plants. It is the active ingredient of herbs such as honeysuckle (Lonicera japonica Thunb) and eucommia (Eucommia ulmoides Oliver). CGA has various biological activities such as antibacterial, anti-inflammation, and maintaining blood sugar balance etc. (Feng et al. 2016; Wu et al. 2016). It also shows good antioxidant properties on scavenging 1,1-diphenyl-2-picrylhydrazyl radical, superoxide anion radical, and hydroxyl radical (Xiang and Ning 2008) and is regarded as an anti-staling agent in food preservation. The addition of CGA inhibited the oxidation of tung oil and oil-in-water emulsions (Sasakia et al. 2010). CGA extracted from Eucommia ulmoides leaves showed significant effect on apple and pear anticorrosive (He and Yang 2015). Chlorogenic acid-gelatin conjugates delayed protein decomposition and lipid oxidation during the storage of sword prawn (Fua et al. 2017).

There are some reports about food preservation that used CGA as one kind of film material, but to our knowledge, the application of CGA on freshwater fish preservation has not yet been studied. Furthermore, most studies focused on assessing the general freshness rather than the inhibition of lipid oxidation during food storage. Therefore, the aim of this work was to explore the quality changes of grass carp with regard to lipid oxidative stability using CGA as a natural inhibitor during chilled storage. At the same time, protein oxidation and color stabilities which are very closely related to lipid oxidation were also measured. Moreover, the mechanism for inhibiting lipid oxidation of CGA for fish muscle was explained by determining endogenous lipase and lipoxygenase activities. Thus, this study provides a comprehensive investigation of the inhibition of lipid oxidation of CGA during fish refrigeration.

\section{Materials and Methods}

\section{Chemicals and Reagents}

Chlorogenic acid was purchased from Melonepharma (Dalian, China). Disodium ethylenediaminetetraacetate dehydrate (EDTA-Na2), 4-nitrophenyl butyrate (4-NPB), and 35component fatty acid methyl esters mixture were obtained from Sigma-Aldrich Chemical Co (St. Louis, MO, USA). Boron trifluoride-methanol solution and 5, 5'-dithiobis 2-nitrobenzoic acid (DTNB) were provided by Yuanye Biological Technology Co. Ltd. (Shanghai, China). Linoleic acid was purchased from Aladdin (Shanghai, China). Methanol (HPLC) was obtained from Fisher Scientific (USA). All other reagents and chemicals used were of analytical grade.

\section{Preparation of Fish Samples}

Fresh grass carp with an average weight of $3.5 \pm 0.5 \mathrm{~kg}(n=20$ in total and four parallel pieces of fish in every test) was purchased from a local fish market (Wuhan, Hubei Province, China). The fish was decapitated, gutted, deboned by hand, and peeled, then cut into pieces $(6 \mathrm{~cm} \times 2 \mathrm{~cm} \times 1 \mathrm{~cm})$ after the red meat was removed due to its uneven distribution. The fish muscles were respectively dipped into $0.05 \%$ (lower), $0.1 \%$ (medium), and $0.3 \%$ (higher) (W/V) CGA aquatic solution (Ju et al., 2018) for $5 \mathrm{~min}$, drained and air-dried for $10 \mathrm{~min}$, then put into small packages individually. Fish muscles treated with distilled water were used as the control group (CONT). All treated samples were stored at $4 \pm 1{ }^{\circ} \mathrm{C}$ and taken for further analysis at days $0,4,8,12$, and 16 .

\section{Lipid Extraction}

The crude lipid was extracted following a previous method (Folch et al. 1957). The fish sample $(50.00 \mathrm{~g})$ was grinded and mixed with $150 \mathrm{~mL}$ of chloroform-methanol solution (2:1, $\mathrm{v} / \mathrm{v})$. The mixture was shaken for $10 \mathrm{~min}$ then another 100 $\mathrm{mL}$ chloroform-methanol solution $(2: 1, \mathrm{v} / \mathrm{v})$ was added and filtered after standing for $1 \mathrm{~h}$. The filtrate was mixed with salt solution (containing $0.73 \% \mathrm{NaCl}$ and $0.05 \% \mathrm{CaCl}_{2}(\mathrm{w} / \mathrm{v})$ ), chloroform, methanol, and water in proportions $8: 4: 3$ by volume. The mixture was centrifuged at $4000 \times g$ for $10 \mathrm{~min}$. The chloroform phase was poured into a flask and evaporated at 40 ${ }^{\circ} \mathrm{C}$ using an evaporator (Yarong RE-3000, Shanghai, China). The residual solvent was removed by flushing nitrogen.

\section{Determination of Lipid Oxidative Stability}

\section{Conjugated Diene}

The lipid sample $(0.0100-0.0500 \mathrm{~g})$ was dissolved in $5 \mathrm{ml}$ isooctane, and the absorbance of the sample was measured with UV-VIS at $234 \mathrm{~nm}$ (Srinivasan et al. 1996). The concentration of conjugated diene was calculated using the molar extinction coefficient of $25,200 \mathrm{M}^{-1} \mathrm{~cm}^{-1}$ and the results were expressed as mol of conjugated diene compounds per kilogram of the lipid sample.

\section{Peroxide Value}

The peroxide value was determined using a ferric thiocyanate method (Shantha and Decker 1994). The crude lipid sample 
$(0.1000 \mathrm{~g})$ was mixed in a glass tube with $9.8 \mathrm{ml}$ chloroformmethanol solution $(7: 3, \mathrm{v} / \mathrm{v})$, then $50 \mu \mathrm{l}$ of $3.94 \mathrm{M}$ ammonium thiocyanate solution and $50 \mu \mathrm{l}$ ferrous chloride (prepared with barium chloride solution and ferrous sulfate solution) solution were added and mixed for 2-4 s. After 5 min incubation, the absorbance of the sample was measured with UV-VIS at 500 $\mathrm{nm}$. Results were expressed as milliequivalents (meq) of peroxide per kilogram of lipid.

\section{Thiobarbituric Acid Reactive Substances}

2-thiobarbituric acid was determined using a former method (Mi et al. 2016) with slight modification. Minced fish muscle $(5.00 \mathrm{~g})$ was homogenized (IKA Ultra-Turrax T18 Basic, Staufen, Germany) with $25 \mathrm{~mL} 7.5 \%$ (w/v) trichloroacetic acid (containing 0.1\% EDTA) for $1 \mathrm{~min}$ at $3000 \mathrm{rpm}$, then centrifuged (Fitchell SF-TDL-5A, Shanghai, China) at a speed of $4000 \times g$ for $10 \mathrm{~min}$. The supernatant $(5 \mathrm{~mL})$ was mixed with thiobarbituric acid $(20 \mathrm{mM}, 5 \mathrm{~mL})$ solution; the mixture was heated in boiling water for $30 \mathrm{~min}$ and cooled with flowing water. The absorbance was measured with ultraviolet-visible spectrophotometer (UV-VIS) at $532 \mathrm{~nm}$ (UNIC UV-2600 UV-Vis, Shanghai, China). The standard curve was prepared by using 1, 1, 3, 3-tetraethoxypropane. The results were expressed as milligrams of malondialdehyde (MDA) per kilogram of fish sample.

\section{Free Fatty Acid}

The content of free fatty acid was determined by titration. The minced fish sample $(5.00 \mathrm{~g})$ was homogenized with $15 \mathrm{ml}$ ether-ethanol solution $(2: 1, \mathrm{v} / \mathrm{v})$ at $3000 \mathrm{rpm}$ for $1-2 \mathrm{~min}$, then centrifuged at a speed of $4000 \times g$ for $5 \mathrm{~min}$ and the supernatant collected. The operation was repeated once as described above. Ten milliliters of supernatant was drawn off into a Erlenmeyer flask, using 1\% phenolphthalein as an indicator; the mixture was titrated with potassium hydroxide solution (0.05M) (Zhao et al. 2009). The free fatty acid content was calculated in $100 \mathrm{~g}$ fish muscle sample.

\section{Carbonyl Value}

Measurement of carbonyl value (COV) was based on a former method previously defined (Han et al. 2014) with little modification. Briefly, the crude lipid sample $(0.0300-0.0500 \mathrm{~g})$ was dissolved in $10 \mathrm{ml} \mathrm{N}$-butanol (purified using reflux heating). One milliliter of this solution was mixed with the same volume of $0.05 \%, 2$, 4-dinitrophenylhydrazine, then heated in $60{ }^{\circ} \mathrm{C}$ water bath for $20 \mathrm{~min}$. The solution was cooled down to room temperature then $8 \mathrm{~mL} 2.5 \%$ potassium hydroxide- $n$-butanol was slowly added and centrifuged at speed of $3000 \times g$ for $5 \mathrm{~min}$. The supernatant was collected and measured with UV-VIS at $420 \mathrm{~nm}$. The carbonyl value was expressed as milliequivalents of carbonyl compounds per kilogram of lipid.

\section{Fatty Acid Composition Analysis}

Fatty acid methyl esters (FAMEs) were prepared using $\mathrm{KOH}$ in methanol. The determination of the fatty acid composition was performed using Agilent 7890A gas chromatography/ mass spectrometer (GC-MS) system (Agilent Technologies, CA, USA). The separation was achieved using a column Thermo TG-5MS ( $30 \mathrm{~m}$ length $\times 0.25 \mathrm{~mm}$ internal diameter $\times 0.25 \mu \mathrm{m}$ film thickness; Waltham, MA, USA). After holding at $80^{\circ} \mathrm{C}$ for $1 \mathrm{~min}$, the temperature was gradually raised to 200 ${ }^{\circ} \mathrm{C}$ at the speed of $10{ }^{\circ} \mathrm{C} / \mathrm{min}$, to $225^{\circ} \mathrm{C}$ with $5{ }^{\circ} \mathrm{C} / \mathrm{min}$, and to $250{ }^{\circ} \mathrm{C}$ with $2{ }^{\circ} \mathrm{C} / \mathrm{min}$, maintained for $5 \mathrm{~min}$, with the injector at $290^{\circ} \mathrm{C}$. Using nitrogen as the carrier gas, the flow rate was set at $1.20 \mathrm{~mL} / \mathrm{min}$ and the sample volume injected was $1 \mu \mathrm{L}$. The standard FAMEs were run under the same conditions. FAMEs in samples were identified by comparing with the retention times of standard FAMEs, and fatty acid compositions were expressed as the area percentage of total FAMEs.

\section{Protein Oxidation Products}

The fish meat sample $(1.00 \mathrm{~g})$ was homogenized with $20 \mathrm{ml}$ buffer solution (containing $0.60 \mathrm{M} \mathrm{NaCl}, 0.05 \mathrm{M} \mathrm{NaH}_{2} \mathrm{PO}_{4}$ $\mathrm{Na}_{2} \mathrm{HPO}_{4}, \mathrm{pH}=7.2$ ) at $10,000 \mathrm{rpm}$ for $30 \mathrm{~s}$. The mixture was centrifuged for $10 \mathrm{~min}$ at a speed of $10,000 \times \mathrm{g}$ (Xiong et al. 2016). The protein content in supernatant was determined by the Lowry method.

\section{Protein Carbonyls}

Two milliliters of $10 \mathrm{mM} \mathrm{2,} \mathrm{4-dinitrophenylhydrazine} \mathrm{(dis-}$ solved in $0.5 \mathrm{M}$ phosphoric acid) was mixed with $2 \mathrm{~mL}$ protein solution and incubated for $10 \mathrm{~min}$ at room temperature. Then, $1 \mathrm{~mL} 6.0 \mathrm{M}$ sodium hydroxide solution was added, to react at room temperature for another $10 \mathrm{~min}$. Absorbance of the solution was measured at $450 \mathrm{~nm}$ (Mesquita et al. 2014). Content of the protein carbonyls was calculated using the molar extinction coefficient of $22,308 \mathrm{M}^{-1} \mathrm{~cm}^{-1}$.

\section{Sulfhydryl Content}

The mixture of $4.5 \mathrm{~mL} 20 \mathrm{mmol} / \mathrm{l}$ Tris-hydrochloric acid buffer (containing 12\% sodium dodecyl sulfate, $10 \mathrm{mM}$ EDTA and $8 \mathrm{M}$ urea, $\mathrm{pH}=6.8$ ), $0.5 \mathrm{ml}$ Ellman solution $(0.1 \%$ 2-nitrobenzoic acid dissolved in Tris-hydrochloric acid buffer, $\mathrm{pH}=6.8$ ) and $0.5 \mathrm{~mL}$ protein solution was placed in 40 ${ }^{\circ} \mathrm{C}$ for $25 \mathrm{~min}$. The absorbance of the sample solution was measured at $412 \mathrm{~nm}$. The content of sulfhydryl was calculated using the molar extinction coefficient of $13,600 \mathrm{M}^{-1} \mathrm{~L} \mathrm{~cm}^{-1}$. 


\section{Color Measurement}

The color was determined with colorimeter (Shang Guang WSC-S, Shanghai, China). The color was measured in three different places on both sides of each steak. L* (brightness), $a^{*}$ (redness -greenness), $b^{*}$ (yellowness -blueness) values were recorded. The whiteness (W) value was calculated using the following formula (Park 1995):

$\mathrm{W}=100-\sqrt{\left(100-\mathrm{L}^{*}\right)^{2}+\mathrm{a}^{* 2}+\mathrm{b}^{* 2}}$

\section{Enzymatic Activities Assay}

\section{Crude Extraction of Endogenous Enzymes}

The extraction of lipase was carried out following a former method (Smichi et al. 2013). The fish samples were homogenized with ten times volume of $25 \mathrm{mM}$ Tris- $\mathrm{HCl}$ buffer (containing $150 \mathrm{mM} \mathrm{NaCl}, 2 \mathrm{mM}$ benzamidine, $\mathrm{pH}=8.0$ ) for $3 \times$ $10 \mathrm{~s}$, then stirred with a magnetic bar (Thermo, Massachusetts, USA) at $4{ }^{\circ} \mathrm{C}$ for $45 \mathrm{~min}$. The mixture was centrifuged for $20 \mathrm{~min}$ at $4{ }^{\circ} \mathrm{C}$ at $10,000 \times \mathrm{g}$. The supernatant was collected for lipase activity measurement.

The assay of lipoxygenase (LOX) activity was measured according to a former method (Gata et al. 1996). The sample was added to $50 \mathrm{mM}$ phosphate buffer (containing $1 \mathrm{mM}$ dithiothreitol, $1 \mathrm{mM}$ EDTA, $\mathrm{pH}=7.4$ ) with the proportion of $5 \mathrm{~mL}$ per $1 \mathrm{~g}$ fish. The mixture was homogenized at $12,000 \mathrm{rpm}$ for $4 \times 10 \mathrm{~s}$, then stirred with a magnetic bar at $4{ }^{\circ} \mathrm{C}$ for $30 \mathrm{~min}$. The suspension was centrifuged at $4{ }^{\circ} \mathrm{C}$ for $20 \mathrm{~min}$ at $10,000 \times g$.

\section{Enzyme Activity}

The lipase activity was measured using the 4-NPB method (Kuepethkaew et al. 2017). The substrate solution was prepared by dissolving $15 \mathrm{mg} 4-\mathrm{NPB}$ into $5 \mathrm{~mL}$ isopropanol. The reaction was carried out by mixing into a tube $200 \mu \mathrm{L}$ diluted lipase with $2.4 \mathrm{~mL} 100 \mathrm{mM}$ Tris- $\mathrm{HCl}$ buffer (containing $0.5 \%$ Triton $\mathrm{X}-100,25 \mathrm{mM} \mathrm{NaCl}, \mathrm{pH}=8.0$ ) and $200 \mu \mathrm{L}$ substrate solution at $37^{\circ} \mathrm{C}$ for $10 \mathrm{~min}$. The absorbance was measured with UVVIS at $410 \mathrm{~nm}$, and one unit of enzyme activity was defined as the enzyme liberated per $\mu \mathrm{mol}$ of $p$-nitrophenol in $1 \mathrm{~min}$.

Substrate solution was prepared by dissolving $140 \mathrm{mg}$ linoleic acid in $10 \mathrm{~mL}$ distilled water, containing $180 \mu \mathrm{L}$ Tween 20 , the $\mathrm{pH}$ of the solution adjusted to 9.0 with $2 \mathrm{M}$ $\mathrm{NaOH}$, and it was diluted with distilled water to a final volume of $50 \mathrm{~mL}$. Subsequently, $200 \mu \mathrm{L}$ crude enzyme was mixed with a citric acid buffer $(2.4 \mathrm{~mL}, 50 \mathrm{mM} \mathrm{pH}=5.5)$ in a tube. After incubation at room temperature for $5 \mathrm{~min}, 200 \mu \mathrm{L}$ substrate solution was added to initialize the reaction. The absorbance at $234 \mathrm{~nm}$ after $1 \mathrm{~min}$ reaction was recorded. One unit of LOX was defined as an increase in absorbance at $234 \mathrm{~nm}$ of 0.001 per min under assay condition.

\section{Statistical Analysis}

The collected data were analyzed by two-way analysis of variance (ANOVA). Duncan's multiple-range tests were used to evaluate the differences between different groups. Statistical significance between mean values was calculated at a significance level of $P<0.05$. All treatments were carried out in triplicate $(n=3)$ and the results are expressed as means \pm standard. Analyses were carried out using IBM SPSS Statistics 19 software.

\section{Results and Discussion}

\section{Effect of Chlorogenic Acid on Lipid Oxidative Stability during Grass-Carp Refrigeration}

\section{Changes of Conjugated Diene}

The conjugated diene value is one parameter which is used to measure the primary stage of lipid oxidation process. Conjugated compounds represent degradation products of polyunsaturated fatty acids, such as linoleic acid and linolenic acid, which are important polyunsaturated fatty acids that exist in grass carp muscles. Figure 1 illustrates that the conjugated diene value increased continuously in all groups during 0-12 days of cold storage. It decreased in the control group after 12 days. The possible reasons for this phenomenon might be that hydroperoxide decomposed into secondary oxidation products such as aldehydes and ketones or formed into a polymer (Johnson and Kummerow 1957). The conjugated diene value

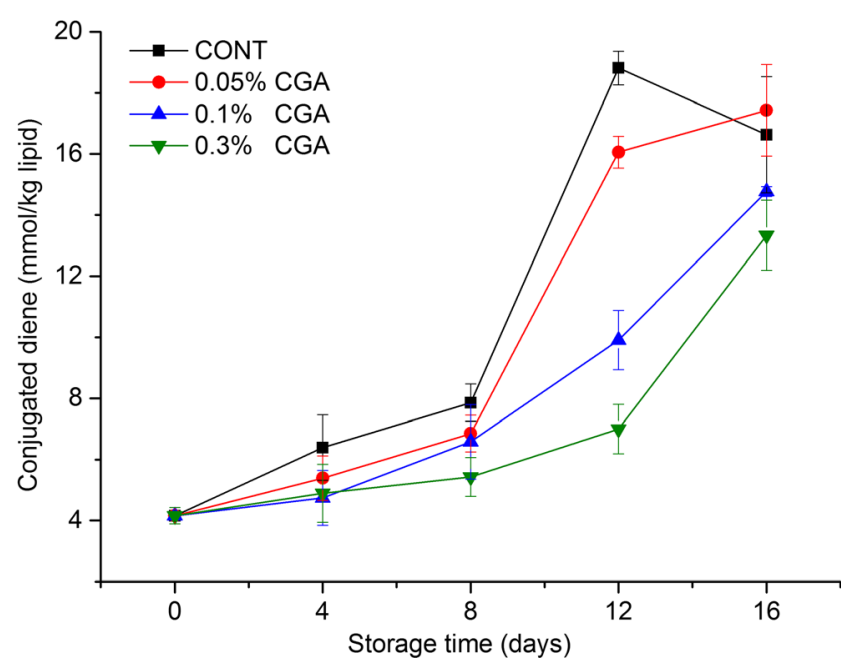

Fig. 1 Changes in TBARS value of grass carp treated with chlorogenic acid during chilled storage 
in $0.3 \%$ CGA treated samples was significantly lower $(P<$ $0.05)$ than that in the control group. Although there was no significant $(P>0.05)$ effect of CGA on inhibiting the conjugated value before 8 days, it remained significant $(P<0.05)$ during 8-16 days of cold storage. A similar tendency occurred in the conjugated diene value found during refrigerated storage of red drum fillets (Mi et al. 2016).

\section{Changes of Peroxide Value}

As an important index to evaluate the generation of lipid hydroperoxide, peroxide value (PV) is the main product in the primary phase of lipid oxidation. The changes of PV in all groups during refrigerated storage are shown in Fig. 2. The PV value was gradually increased during the 12 days of storage in all groups, indicating that the lipid oxidation always exists even in low temperatures. The formation rate of hydroperoxide was faster than the decomposition rate during the early stage of storage, so hydrogen peroxide gradually accumulated. Concentration of hydroperoxide in the control group was significantly $(P<0.05)$ higher than that in the $0.1 \%$ or $0.3 \%$ CGA groups during 12 days. After 12 days of cold storage, the PV in the control and $0.05 \%$ CGA groups sharply declined, as the hydroperoxide might have decomposed into secondary oxidation products in the later stage of lipid oxidation (Chauhan et al. 2018). However, PV in the grass carp muscle treated with $0.1 \%$ and $0.3 \%$ CGA kept rising; thus, higher concentration of CGA may be delayed due to hydroperoxide decomposition. These results indicate that higher concentration of CGA showed better inhibitory effect on lipid oxidation. Similar results were found in minced Atlantic mackerel (Scomberscombrus) when water extract of Polysiphonia fucoides was added to inhibit the degradation of peroxide during refrigeration (Babakhani et al. 2016).

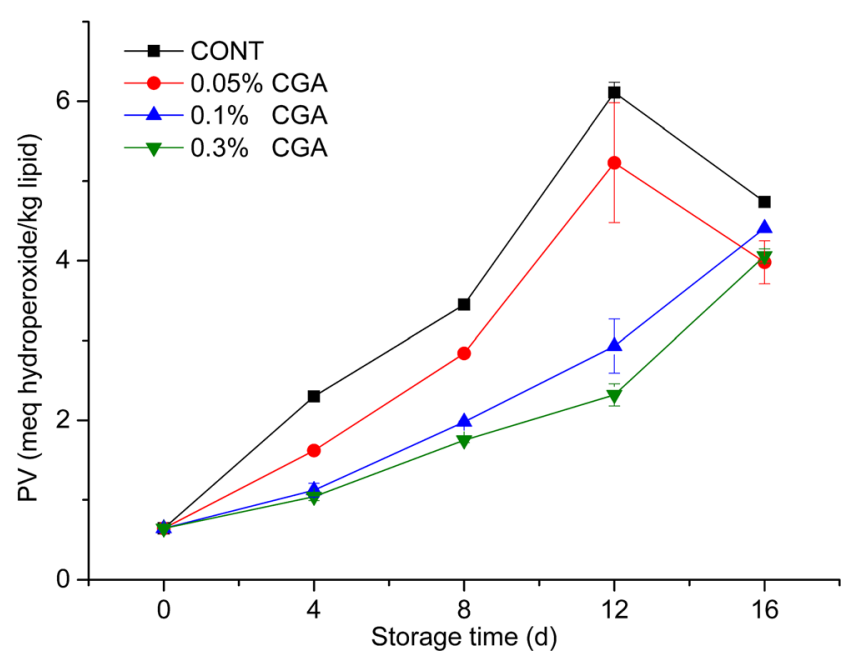

Fig. 2 Changes in PV of grass carp treated with chlorogenic acid during chilled storage

\section{Changes of Thiobarbituric Acid Reactive Substances}

The thiobarbituric acid reactive substances (TBARS) value is a key index to evaluate the lipid oxidation. The primary oxidation product of polyunsaturated fatty acids is hydroperoxide, and TBARS reflect the content of malonaldehyde (MDA), which is the secondary lipid oxidation product generated from the degradation of lipid hydroperoxide (Aubourg 1993). The TBARS values gradually increased in all groups during chilled storage (Fig. 3); the amount of MDA was significantly higher than the fresh fish after 16 days in all the samples $(P<0.05)$, which suggests that hydroperoxide was continually broken down to secondary products. Groups treated with CGA had lower TBARS values than the control group, and the content of MDA was decreased with the rise of chlorogenic acid concentration. This observation indicated that CGA could reduce the degradation of lipid hydroperoxide during chilled storage. During 16 days storage, although the TBARS values of the $0.05 \%$ CGA group showed no significant difference compared with the control group $(P>0.05)$, the $0.3 \%$ CGA group illustrated significant decrease in the TBARS values $(P<0.05)$. The content of MDA was significantly $(P<0.05)$ reduced from the $0.3 \%$ CGA group and the $0.1 \%$ CGA group after 8 days. That means CGA could slow down the lipid oxidation or peroxidation during grass carp storage. A similar finding was reported that pepper (Zanthoxyoum Bungeanum maxim) leaf extract which is rich in chlorogenic acid and quercetin could reduce TBARS values and inhibit the lipid peroxidation of salted silver carp during processing (Li et al. 2015).

The content of MDA in the control group was $0.62 \pm$ $0.03 \mathrm{mg} \mathrm{MDA} / \mathrm{kg}$ fish after 4 days, but for the $0.3 \%$ CGA treated group, it was decrease to $0.50 \pm 0.01 \mathrm{mg}$ $\mathrm{MDA} / \mathrm{kg}$ fish after 12 days, which was even lower than the content in the control group after four days. Thus, it was demonstrated that higher concentrations of CGA

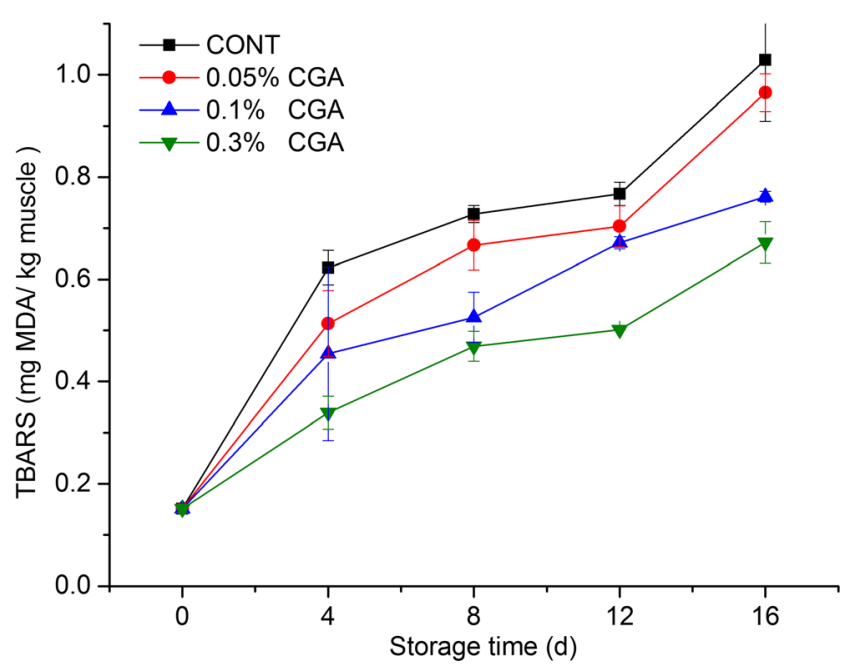

Fig. 3 Changes in FFA content of grass carp treated with chlorogenic acid during chilled storage 
treatment could effectively limit lipid oxidation and extend the shelf life of grass carp during cold storage.

\section{Changes of Free Fatty Acid}

Free fatty acid is mainly obtained from the hydrolysis of glycerol fatty acid ester; in addition, the decomposition of unstable hydroperoxide can also produce some short-chain fatty acids (Qiu et al. 2014). Thus, free fatty acid (FFA) was selected as one key index to evaluate the degree of lipid oxidation in this study. The content of FFA was very low in fresh grass carp muscle and increased in all groups during storage (Fig. 4), indicating that grass carp fish fillet was continuously hydrolyzed. The FFA content of the control group was significantly $(P<0.05)$ higher than that of the $0.1 \%$ CGA and $0.3 \%$ CGA groups. Basically, the content of FFA increased from low concentration of CGA treatment to higher concentration during storage. A sharp increase in FFA content was observed in the control and $0.05 \%$ CGA groups during 4-8 days, but the same tendency to increase for the $0.1 \% \mathrm{CGA}$ and $0.3 \%$ CGA groups occurred during 8-12 days. Results indicate that high concentration of CGA could affect the production of FFA. Similar results were reported in recent work (Miranda et al. 2018). In such study, the FFA content of lean fish progressively increased and the high concentration batch of Bifurcaria bifurcata alga extract treatment significantly retarded FFA formation during chilled storage. Previous studies showed that microbial activity also contributed to the increase of FFA content and was mostly responsible for lipid hydrolysis after 9 days of storage (Campos et al. 2012; Miranda et al. 2018). This indicates that CGA has effects on inhibiting microbial activities in grass carp fish muscle.

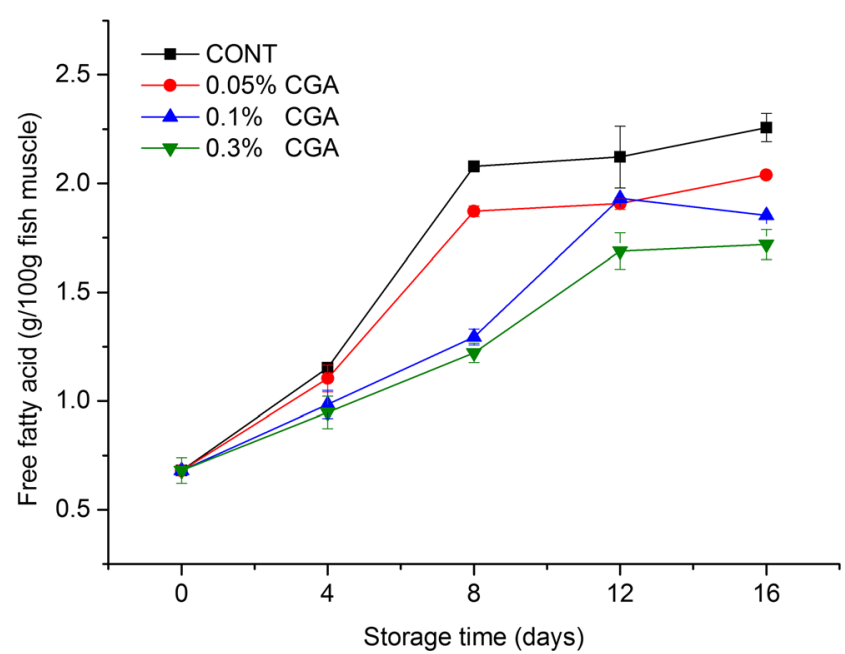

Fig. 4 Changes in COV of grass carp treated with chlorogenic acid during chilled storage

\section{Changes of Carbonyl Value}

The COV reflects the total amount of carbonyl compounds such as aldehyde and ketone, which are the crucial secondary products of lipid oxidation. Therefore, the COV is usually regarded as one of the important indexes for lipid oxidation. Results of COV measurement about the grass carp storage are shown in Fig. 5. It is clear to see that COV went up during 0-8 days in all groups, and it reached the peak value in the control group on day 8 . The rise in $\mathrm{COV}$ due to the constant production of free fatty acids provided enough peroxide which can decompose carbonyl compounds ( $\mathrm{Li}$ et al. 2016). The COV declined rapidly in the control group after the 8th day, but it increased in the treated groups during $8-12$ days of storage. The COV peaked in the treated groups on the 12th day. Polymerization, degradation, or other reaction of carbonyl compounds in the late period of lipid oxidation led to the reduction in $\mathrm{COV}(\mathrm{Li}$ and Huan 2017). The highest contents of carbonyl compound in $0.1 \%$ CGA (50.53 meq $/ \mathrm{kg}$ lipid) and $0.3 \%$ CGA groups $(36.65 \mathrm{meq} / \mathrm{kg}$ lipid) were significantly $(P<0.05)$ lower than that of the control group $(69.76 \mathrm{meq} / \mathrm{kg}$ lipid). The results reveal that CGA treatment could evidently decrease the formation of carbonyl compounds to some extent.

\section{Changes in Fatty Acid Profiles}

Usually, fatty acid profiles are closely related to lipid oxidation, and changes in the content of different fatty acids in grass carp muscles might reflect the extent of lipid oxidation. Therefore, fatty acid profiles of fish muscle samples were assessed in this study. The changes of fatty acid composition in total lipid extracted from the CONT and $0.3 \%$ CGA groups are listed in Table 1. Fresh grass carp meat contained a high proportion of polyunsaturated fatty acid (PUFA), especially linoleic acid (C18:2n-6), eicosatetraenoic acid (C20:4n-6),

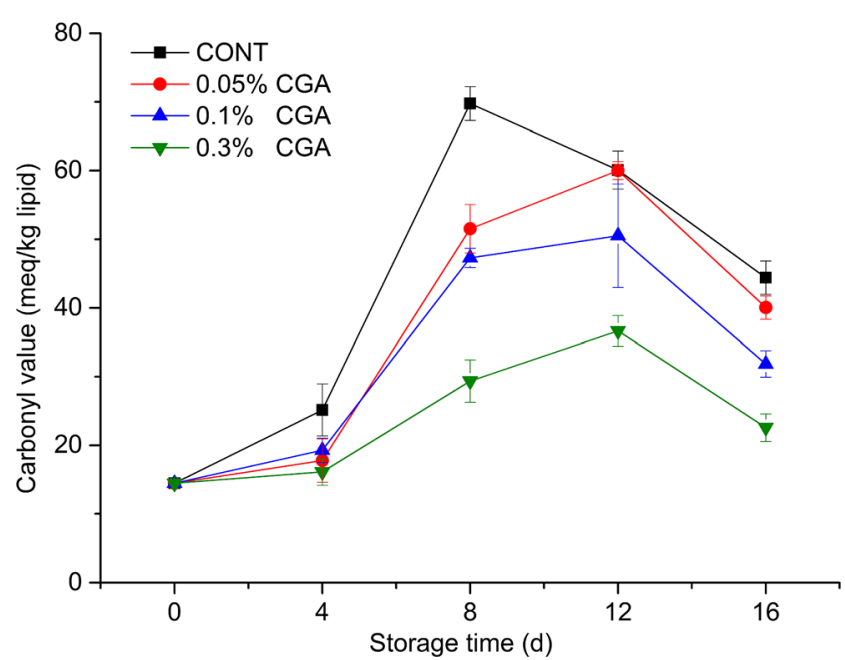

Fig. 5 Changes in conjugated diene value of grass carp treated with chlorogenic acid during chilled storage 


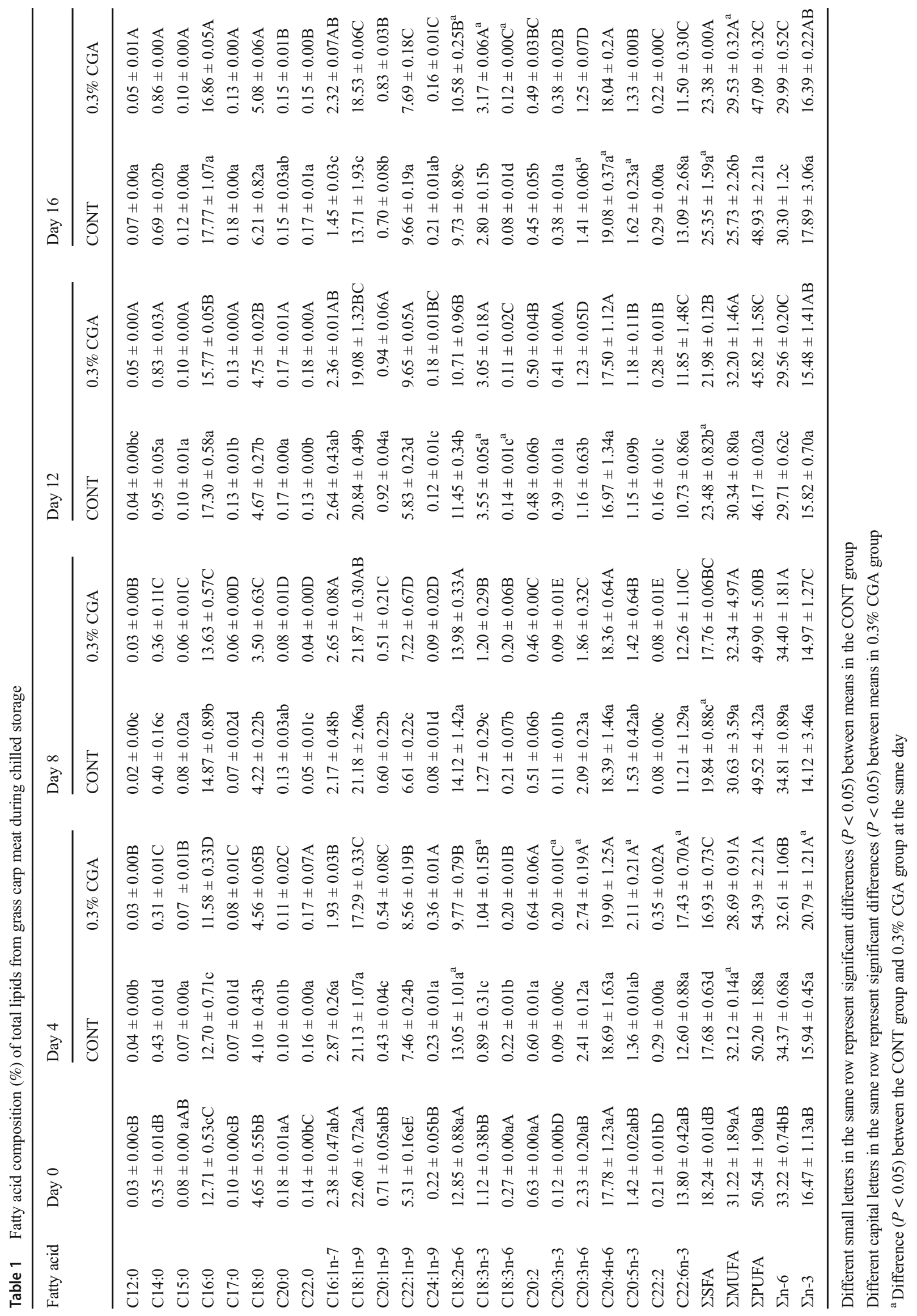


and DHA (C22:6n-3). Palmitic acid (C16:0) and oleic acid (C18:1n-9) were dominant in saturated fatty acid (SFA) and monounsaturated fatty acid (MUFA), respectively.

The concentration of total SFA increased during storage, as well as the percentages of C16:0 and stearic acid (C18:0). The content of total SFA was significantly $(P<0.05)$ lower in fish muscle treated with $0.3 \%$ CGA after 8 days of preservation. The content of C16:0 in the control group was also higher than in the CGAtreated group during 16 days of cold storage. These results indicate that CGA was efficient in retarding the SFA formation. A decrease was observed in the concentration of SFA during 0-4 days, and a similar phenomenon was found in a previous report, that total SFA content decreased slightly during 4-day cold storage of mussel (Mytilus edulis) and meat (Zhou et al. 2019).

It is well known that cis-MUFA has an obvious effect on the decrease of cholesterol. The amount of total MUFA declined during 12-16 days of storage in the CONT; however, there was no change $(P>0.05)$ in the $0.3 \%$ CGA group during the entire cold storage period. The proportion of dodecanoic acid (C22:1n-9) increased in both groups and was higher in the CGA-treated samples. The results demonstrate that CGA had an effect on maintaining the content of total MUFA and to some extent prevented MUFA from oxidative reactions.

PUFA is expected to be the easiest oxidized component, and the content of PUFA decreases due to lipolysis, autoxidation, and catalysis reactions that occur during the preservation process. PUFA in the grass carp muscle is primarily comprised of long-chain n-3 PUFA and n-6 PUFA, which are essential for human health. In this study, the content of total PUFA in grass carp muscle treated with $0.3 \%$ CGA increased during 0-4 days; no obvious change was found in the control group. However, the amount of PUFA in the $0.3 \%$ CGA group decreased significantly $(P<0.05)$ during $4-16$ days of preservation, but that in the control group remained unchanged $(P>0.05)$. The percentage of total PUFA indicated no significant $(P>0.05)$ difference between the two groups throughout the storage. Putri Widyanti reported that $\mathrm{C} 18: 2 \mathrm{n}-6$ and linolenic acid (C18:3n-3) can transform into long-chain PUFAs through the enzymatic effect, which may explain the increase in some kinds of fatty acids (Harlina et al. 2019). The changes in proportions of C18:2n-6, C18:3n-3, EPA, and DHA demonstrated that the inhibitory effect on PUFA oxidation of CGA was significant $(P<0.05)$ during $0-4$ days.

The proportion of $n-6$ PUFAs/n-3 PUFAs in fresh fish was 2.02. Proportions in fish treated with and without CGA were 1.83 and 1.69 on the 16th day. This indicates that n-6 PUFAs degraded faster than n-3 PUFAs during the period of chilled storage.

\section{Effect of Chlorogenic Acid on Protein Oxidation}

There is a relationship between lipid oxidation and protein oxidation during the food preservation system. Primary and secondary products of lipid oxidation may accelerate protein oxidation, and protein oxidation can also mediate lipid oxidation (Choe et al. 2017). Therefore, the effect of CGA on protein oxidation is a supplementary explanation to the assessment of CGA as a potential inhibitor of lipid oxidation.

Carbonyl content is one of the most frequently used indicators for evaluating protein oxidation. Some amino acids, such as arginine, histidine, lysine, and proline, generate carbonyl compounds through oxidative degradation. Moreover, the production of carbonyl compounds has bad effects on the quality of meat (Babakhani et al. 2015). Figure 6 a shows the changes in protein carbonyls in the groups with different concentration of CGA treatment. After 16 days of storage, the carbonyl content increased significantly $(P<0.05)$ in all groups, and the carbonyls of all the CGA-treated groups were

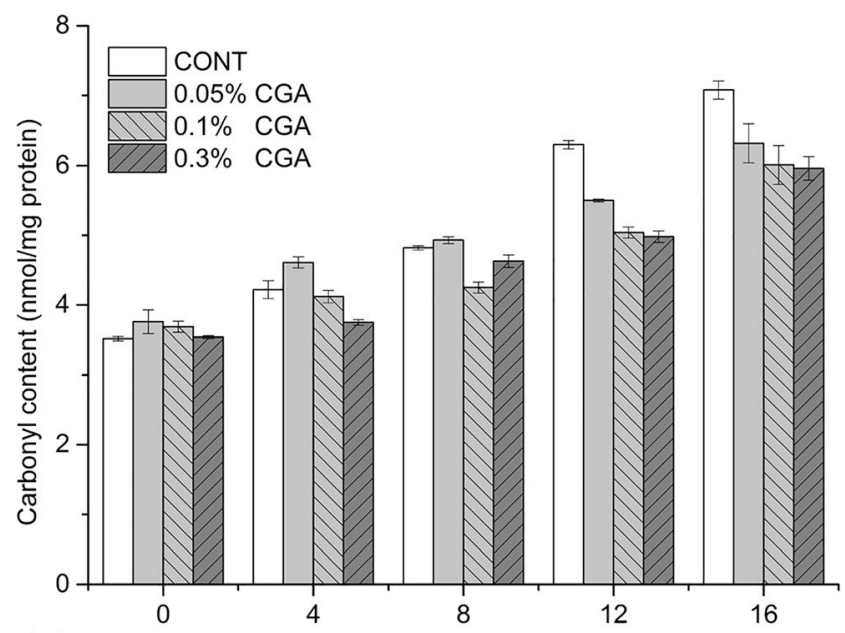

(a)

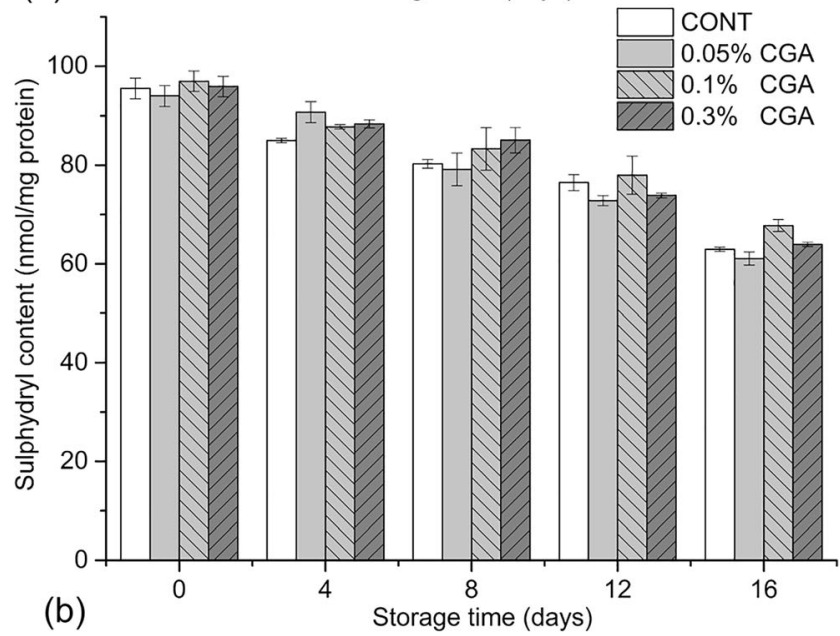

Fig. 6 Changes in protein oxidation of grass carp treated with chlorogenic acid during chilled storage. a Carbonyl content. b Sulfhydryl content 
significantly $(P<0.05)$ lower than the control group. The results show that protein oxidation occurred in grass carp muscle precisely during cold storage, and CGA was efficient in retarding amino acid decomposition and protein oxidation. However, during 16 days of the storage period, the $0.3 \%$ CGA group did not show a better inhibitory effect on the generation of carbonyl compounds than the $0.1 \%$ CGA group, which did not coincide with the results of lipid oxidation.

Sulfhydryl content is used to evaluate cysteine oxidation, which induces the formation of intermolecular disulfide bridges. The loss of sulfhydryl content has been used as an important index of protein oxidation in aquatic products. Sulfhydryl group content declined sharply for all samples in 16 days storage, as shown in Fig. 6b, indicating that the sulfhydryl group oxidized during storage. The reason might be that sulfhydryl converted into disulfide bonds and other oxidation products preceding protein oxidation (Dean et al. 1997). The greatest decrease in sulfhydryl was observed in the control group (from 95.48 to $62.59 \mathrm{nmol} / \mathrm{mg}$ protein); total sulfhydryl content in the $0.1 \%$ and $0.3 \%$ CGA-treated samples was significantly higher than the control group $(P<0.05)$. No difference was found between the $0.3 \%$ and $0.1 \%$ CGA groups during 0-8 days, the sulfhydryl content was even higher in the $0.1 \%$ CGA-treated samples after 8 days of storage. This suggests that the ability to inhibit protein oxidation cannot be improved with the increase of CGA concentration. These results correspond with those in carbonyl content.

The previous dipping treatment of CGA may form a coating on the grass carp surface, while the antioxidant activity and the antimicrobial property of polyphenol provide the fish with good protection from deterioration during chilled storage. There are other studies that reached a similar conclusion (Miranda et al. 2018; Wu et al. 2016).

\section{Effect of Chlorogenic Acid on Color Stability}

Color is one of the important criteria for consumers to evaluate meat quality and influence consumption desire. The effect of CGA on color changes of fish muscle are shown in Table 2. At the beginning of storage (day 0$)$, no difference $(P>0.05)$ was found between the control group and the CGA-treated groups in whiteness $(\mathrm{W})$ value. After 16 days storage, the $\mathrm{W}$ value significantly $(P<0.05)$ increased in all groups, because of the reduction of water retention and adhesion of moisture on the surface of fish muscle. At the same time, the $\mathrm{L}^{*}$ value of fish samples rose, which was affected by the degree of protein oxidation. Compared with fresh fish muscle, $a^{*}$ value $(P<$ 0.05 ) significantly decreased in all groups after 16 days, while

Table 2 Measurement of color stability in grass carp during chilled storage

\begin{tabular}{|c|c|c|c|c|c|}
\hline \multirow[t]{2}{*}{ Parameters } & \multirow[t]{2}{*}{ Storage time (days) } & \multicolumn{4}{|l|}{ Sample } \\
\hline & & CONT & $0.05 \%$ CGA & $0.1 \% \mathrm{CGA}$ & $0.3 \%$ CGA \\
\hline \multirow[t]{5}{*}{$\mathrm{L}$} & 0 & $50.39 \pm 0.43 \mathrm{aB}$ & $50.82 \pm 0.73 \mathrm{aC}$ & $50.53 \pm 0.32 \mathrm{aC}$ & $50.19 \pm 0.74 \mathrm{aC}$ \\
\hline & 4 & $50.93 \pm 1.06 \mathrm{bB}$ & $51.35 \pm 0.66 \mathrm{bBC}$ & $52.23 \pm 0.57 \mathrm{aB}$ & $52.85 \pm 0.41 \mathrm{aAB}$ \\
\hline & 8 & $51.76 \pm 0.85 \mathrm{cA}$ & $52.77 \pm 1.18 \mathrm{abA}$ & $53.63 \pm 0.60 \mathrm{aA}$ & $52.05 \pm 0.82 \mathrm{bcB}$ \\
\hline & 12 & $52.30 \pm 0.59 \mathrm{bA}$ & $52.28 \pm 0.53 \mathrm{bA}$ & $53.67 \pm 0.70 \mathrm{aA}$ & $52.60 \pm 0.51 \mathrm{bB}$ \\
\hline & 16 & $52.01 \pm 0.41 \mathrm{bA}$ & $52.14 \pm 0.55 \mathrm{bAB}$ & $52.40 \pm 0.58 \mathrm{bB}$ & $53.54 \pm 0.99 \mathrm{aA}$ \\
\hline \multirow[t]{5}{*}{$a^{*}$} & 0 & $0.08 \pm 0.23 \mathrm{aA}$ & $0.51 \pm 0.37 \mathrm{aA}$ & $0.67 \pm 0.23 \mathrm{aA}$ & $0.24 \pm 0.09 \mathrm{aA}$ \\
\hline & 4 & $0.15 \pm 0.16 \mathrm{aA}$ & $-1.16 \pm 0.14 \mathrm{bB}$ & $-1.10 \pm 0.24 b C$ & $-1.23 \pm 0.11 b B$ \\
\hline & 8 & $-0.56 \pm 0.28 \mathrm{abB}$ & $0.08 \pm 0.31 \mathrm{aA}$ & $-0.58 \pm 0.24 \mathrm{abB}$ & $-1.12 \pm 0.04 b B$ \\
\hline & 12 & $-1.20 \pm 0.21 \mathrm{aC}$ & $-1.39 \pm 0.22 \mathrm{aB}$ & $-1.77 \pm 0.32 b D$ & $-1.02 \pm 0.14 \mathrm{aB}$ \\
\hline & 16 & $-1.55 \pm 0.43 b C$ & $-1.22 \pm 0.25 \mathrm{aB}$ & $-1.03 \pm 0.25 \mathrm{aC}$ & $-1.16 \pm 0.16 \mathrm{aB}$ \\
\hline \multirow[t]{5}{*}{$b^{*}$} & 0 & $-0.77 \pm 0.29 \mathrm{aB}$ & $-0.69 \pm 0.16 \mathrm{aAB}$ & $-0.63 \pm 0.05 \mathrm{aA}$ & $-0.94 \pm 0.29 \mathrm{aB}$ \\
\hline & 4 & $0.56 \pm 0.26 \mathrm{aA}$ & $-0.38 \pm 0.21 \mathrm{bA}$ & $-0.53 \pm 0.17 \mathrm{bA}$ & $-0.84 \pm 0.20 \mathrm{bAB}$ \\
\hline & 8 & $0.28 \pm 0.45 \mathrm{aA}$ & $-0.22 \pm 0.14 \mathrm{aA}$ & $-0.08 \pm 0.26 \mathrm{aA}$ & $-0.01 \pm 0.34 \mathrm{aA}$ \\
\hline & 12 & $-1.18 \pm 0.25 \mathrm{aBC}$ & $-0.95 \pm 0.06 \mathrm{aAB}$ & $-0.93 \pm 0.57 \mathrm{aA}$ & $-0.79 \pm 0.21 \mathrm{aB}$ \\
\hline & 16 & $-1.86 \pm 0.36 \mathrm{bC}$ & $-1.78 \pm 0.41 \mathrm{bB}$ & $-0.81 \pm 0.34 \mathrm{aA}$ & $-1.18 \pm 0.29 b B$ \\
\hline \multirow[t]{5}{*}{ W } & 0 & $50.38 \pm 0.70 \mathrm{aB}$ & $50.80 \pm 0.54 \mathrm{aC}$ & $50.52 \pm 0.68 \mathrm{aC}$ & $50.16 \pm 0.69 \mathrm{aC}$ \\
\hline & 4 & $50.92 \pm 0.89 \mathrm{bB}$ & $51.23 \pm 0.65 \mathrm{bBC}$ & $52.20 \pm 0.53 \mathrm{aB}$ & $52.82 \pm 0.49 \mathrm{aAB}$ \\
\hline & 8 & $51.74 \pm 0.74 \mathrm{aA}$ & $52.75 \pm 0.94 \mathrm{aA}$ & $53.62 \pm 0.78 \mathrm{aA}$ & $52.03 \pm 0.57 \mathrm{aB}$ \\
\hline & 12 & $52.26 \pm 0.79 \mathrm{bA}$ & $52.24 \pm 0.86 \mathrm{bA}$ & $53.61 \pm 0.76 \mathrm{aA}$ & $52.56 \pm 0.67 \mathrm{bB}$ \\
\hline & 16 & $51.95 \pm 0.62 \mathrm{bA}$ & $52.10 \pm 0.74 \mathrm{bAB}$ & $52.36 \pm 0.43 \mathrm{bB}$ & $53.40 \pm 0.57 \mathrm{aA}$ \\
\hline
\end{tabular}

Different small letters within the same row represent significant differences $(P<0.05)$ between groups. Different capital letters within the same column represent significant differences $(P<0.05)$ between days 
$\mathrm{b}^{*}$ value showed no difference $(P>0.05)$ in CGA-treated groups. The results indicate that the color of fish muscle turned from reddish to greenish during cold storage; this phenomenon might be due to the oxidation of myoglobin pigment in grass carp muscle (Zakaria and Sarbon 2018). The W values in the higher CGA concentration-treated groups were significantly $(P<0.05)$ increased than those in the control group at the end of storage. Chlorogenic acid improved the color of grass carp muscle, probably because polyphenols distorted or broke protein covalent bonds, and to a certain extent, the structure of protein got denatured and agglutinated (Feng et al. 2016). Similar changes in luminosity and red color were found in chilled minced pork coated with chitosan essential oil films, which had good oxygen barrier capacity (Bonilla et al. 2014). The whiteness of hake (Gadus) also increased after 7 days of conventional storage $(0.1 \mathrm{MPa}, 5$ ${ }^{\circ} \mathrm{C}$ ) (Otero et al. 2017).

\section{Effect of Chlorogenic Acid on Enzyme Activity}

Lipase and LOX are two kinds of active endogenous enzymes which are involved in lipid oxidation during fish preservation. The actions of lipase and LOX are closely associated with biochemical reactions in lipid oxidation, such as the hydrolysis of triglyceride and the formation of hydroperoxide (Fidalgo et al. 2015). In order to obtain a more comprehensive understanding of the inhibition of CGA to lipid oxidation, the changes in endogenous lipase and LOX activities of fish samples were measured as illustrated in Fig. 7.

From Fig. 7a, it is shown that the lipase activities of both groups increased $(P<0.05)$ during $0-4$ days and declined during 4-16 days on the whole. A similar tendency was also reported in a former study (Zhou et al. 2019). The lipase activity of the $0.3 \%$ CGA-treated group is significantly $(P<$ 0.05 ) lower than the control during 8 days of storage. There were no differences in lipase activities between CGA treated and control groups from days 12 to days 16 of storage. The results indicate that CGA can induce lipase activity in fish muscle to go down which maybe one of the main reasons of its inhibitory effect on lipid oxidation. The changes in LOX activities of fish muscle during storage are depicted in Fig. 7b. The LOX activity increased significantly $(P<0.05)$ during $0-4$ days in the control group; however, it showed no difference $(P>0.05)$ in the $0.3 \%$ CGA-treated samples. The activity of LOX in the $0.3 \%$ CGA-treated group was significantly $(P<0.05)$ lower than that in the control group during $0-12$ days of cold storage. Results demonstrate that CGA can be an effective inhibitor of lipid oxidation during grass carp refrigeration by decreasing LOX activity. With the effect of the oxidation progress, the lipid and fatty acids available might be limited for LOX, which explains why lipid oxidation products are not formed to a high level at the end of storage
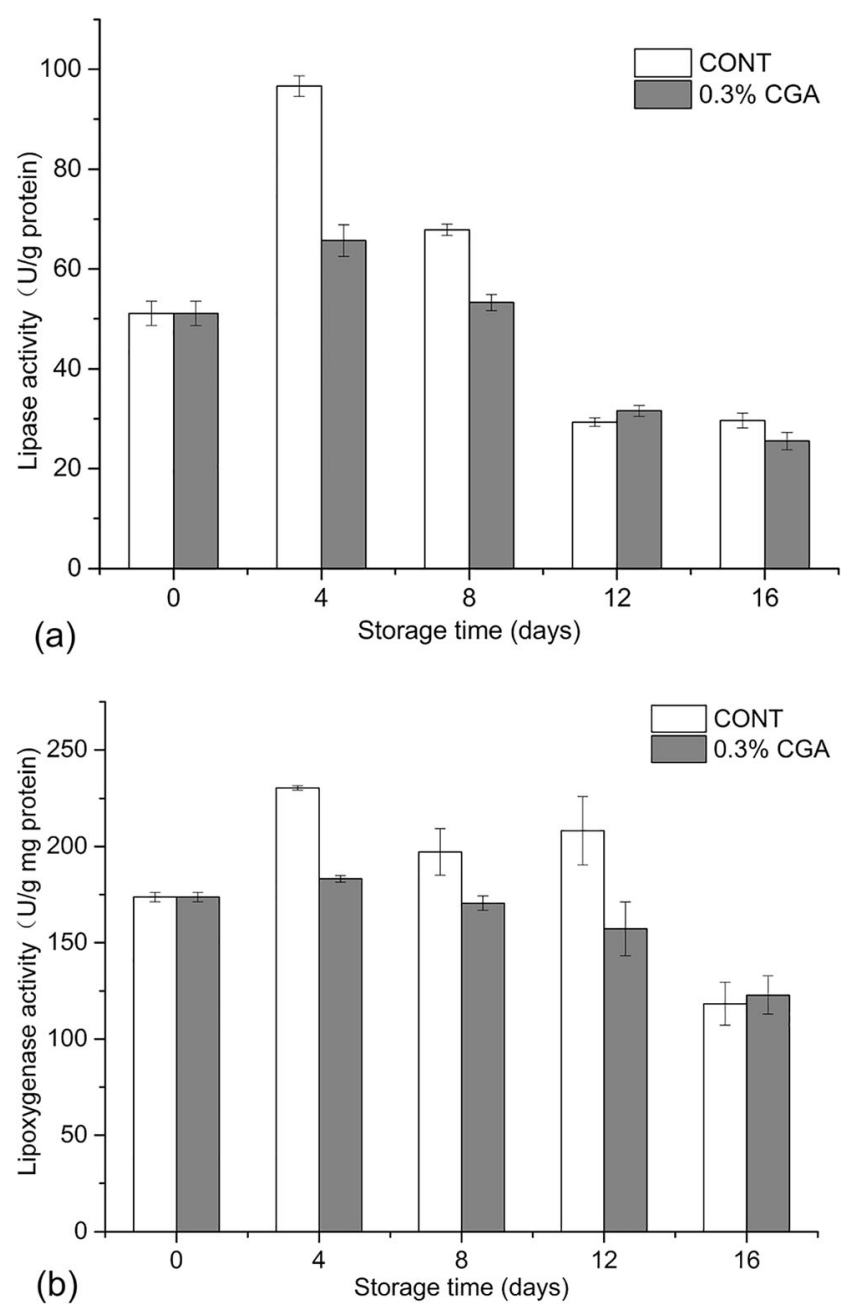

Fig. 7 Changes in a lipase and $\mathbf{b}$ lipoxygenase activities of grass carp supplement with chlorogenic acid during chilled storage

(Sae-leaw and Benjakul 2014). The trend of endogenous enzyme activities is confirmed with the results of parameters of lipid oxidation such as FFA and PV during storage.

\section{Conclusion}

The present study investigated the inhibiting effect of CGA with different concentrations $(0,0.05 \%, 0.1 \%$, and $0.3 \%)$ on lipid and protein oxidation in grass carp during chilled storage. The results showed that CGA has good efficiency in retarding further deterioration of grass carp and extended its shelf life during the storage period. According to the TBARS value, PV, COV, FFA content and CD content, the inhibition effect of CGA increased as the concentration rose; thus, $0.3 \%$ CGA provided the best fresh-keeping effect according to the formation of primary and secondary oxidative products. CGA treatment also prevented the increase of SFA and the decrease of MUFAs in grass carp muscle, but the degradation of PUFA 
was less affected. The degree of protein oxidation in fish samples treated with $0.1 \%$ and $0.3 \%$ CGA was less than the control group. The significant enzyme activity decrease of lipase and LOX in CGA-treated groups provided useful information to our understanding of the mechanism inhibiting lipid oxidation of CGA during the storage period. Therefore, CGA as a novel natural additive could be used to inhibit lipid and protein oxidation and has good prospects to its application on aquatic products.

Funding Information This study was supported by the Nature Science Foundation of China (No. 31772047), the Fundamental Research Funds for the Central universities (No. 2662019PY031), and the China Agriculture Research System (CARS-45-27).

\section{References}

Abimannan, A., Sadayan, P., \& Miranda, J. M. (2018). Combined effect of icing medium and red alga Gracilaria verrucosa on shelf life extension of Indian mackerel (Rastrelliger kanagurta). Food and Bioprocess Technology., 11(10), 1911-1922.

Alves, V., Rico, B., Cruz, R., Vicente, A. A., Khmelinskii, I., \& Vieira, M. (2018). Preparation and characterization of a chitosan film with grape seed extract-carvacrol microcapsules and its effect on the shelf-life of refrigerated salmon ( Salmo salar ). LWT - Food Science and Technology., 89, 525-534.

Aubourg, S. P. (1993). Review: interaction of malondialdehyde with biological molecules- new trends about reactivity and significance. International Journal of Food Science and Technology, (28), 323325.

Babakhani, A., Farvin, K. H. S., \& Jacobsen, C. (2015). Antioxidative effect of seaweed extracts in chilled storage of minced atlantic mackerel (scomber scombrus): effect on lipid and protein oxidation. Food and Bioprocess Technology., 9(2), 352-364.

Babakhani, A., Farvin, K. H. S., \& Jacobsen, C. (2016). Antioxidative effect of seaweed extracts in chilled storage of minced Atlantic mackerel (Scomber scombrus): effect on lipid and protein oxidation. Food and Bioprocess Technology., 9(2), 352-364.

Bonilla, J., Vargas, M., Atarés, L., \& Chiralt, A. (2014). Effect of chitosan essential oil films on the storage-keeping quality of pork meat products. Food and Bioprocess Technology., 7(8), 2443-2450.

Campos, C. A., Gliemmo, M. F., Aubourg, S. P., \& Velázquez, J. B. (2012). Novel technologies for the preservation of chilled aquatic food products. In McElhatton IA \& Sobral PA (eds) Novel technologies in food science. $p^{\wedge} p p$ (pp. 299-323). NewYork, USA: Springer.

Cerutti, P. A. (1985). Prooxidant states and tumor promotion. Science and Technology of Food Industry., 227(4685), 375-381.

Chauhan, P., Das, A., Nanda, P. K., Kumbhar, V., Yadav, J. P., \& Ganji, V. (2018). Effects of nigella sativa seed extract on lipid and protein oxidation in raw ground pork during refrigerated storage. Nutrition \& Food Science., 48(1), 2-15.

Choe, J.-H., Kim, H.-Y., \& Kim, C.-J. (2017). Effect of persimmon peel (Diospyros kaki thumb.) extracts on lipid and protein oxidation of raw ground pork during refrigerated storage. Korean Journal for Food Science of Animal Resources., 37(2), 254-263.

Dean, R. T., Fu, S., Stocker, R., \& Davies, M. J. (1997). Biochemistry and pathology of radical-mediated protein oxidation. Biochemical Journal., 324(1), 1-18.

Feng, X., Ng, V. K., Mikš-Krajnik, M., \& Yang, H. S. (2017). Effects of fish gelatin and tea polyphenol coating on the spoilage and degradation of myofibril in fish fillet during cold storage. Food and Bioprocess Technology., 10(1), 89-102.

Feng, Y., Yu, Y. H., Wang, S. T., Ren, J., Camer, D., \& Hua, Y. Z. (2016). Chlorogenic acid protects d-galactose-induced liver and kidney injury via antioxidation and anti-inflammation effects in mice. Pharmaceutical Biology., 54(6), 1027-1034.

Feng, Z., Chen, H., Guo, L. P., Xiong, S. L., \& Huang, Y. Z. (2016). Effects of high pressure combined with thermal treatment on myoglobin in pork. Science and Technology of Food Industry., 37(2), $160-164$.

Fidalgo, L. G., Saraiva, J. A., Aubourg, S. P., Vázquez, M., \& Torres, J. A. (2015). Enzymatic activity during frozen storage of Atlantic horse mackerel (Trachurus trachurus) pre-treated by high-pressure processing. Food and Bioprocess Technology., 8(3), 493-502.

Folch, J., Lees, M., \& Stanley, G. H. S. (1957). A simple method for the isolation and purification of total lipids from animal tissues. Journal of Biological Chemistry., 226(1), 497-509.

Fua, S. L., Wu, C. H., Wu, T. T., Yu, H. X., Yang, S. B., \& Hu, Y. Q. (2017). Preparation and characterisation of chlorogenic acid-gelatin: a type of biologically active film for coating preservation. Food Chemistry., 221(15), 657-663.

Gata, J. L., Pinto, M. C., \& Macias, P. (1996). Lipoxygenase activity in pig muscle: purification and partial characterization. Journal of Agricultural and Food Chemistry., 44(9), 2573-2577.

Han, R.-Y., Lan, F., Hong, L., Liu, L., Cai, L., \& Hiu, L.-X. (2014). Rapid determination of carbonyl value in frying oils by 1-butanol constant method. Journal of Food Safety and Quality., 11(5), 3501-3508.

Harlina, P. W., Shahzad, R., Ma, M., Wang, N., \& Qiu, N. (2019). Effects of galangal extract on lipid oxidation, antioxidant activity and fatty acid profiles of salted duck eggs. Journal of Food Measurement and Characterization., 13(3), 1820-1830. https://doi.org/10.1007/ s11694-019-00100-z.

He, N. W., \& Yang, C. (2015). Extraction of chlorogenic acid from leaves of Eucommia ulmoides and its application in preservation of fruits and vegetables. Acta Agriculturae Jiangxi., 7, 107-110.

Johnson, O. C., \& Kummerow, F. A. (1957). Chemical changes which take place in an edible oil during thermal oxidation. Journal of the American Oil Chemists Society., 34(8), 407-409.

Ju, J., Liao, L., Qiao, Y., Xiong, G., Li, D., \& Wang, C. (2018). The effects of vacuum package combined with tea polyphenols $(v+t p)$ treatment on quality enhancement of weever ( micropterus salmoides ) stored at $0^{\circ} \mathrm{C}$ and $4{ }^{\circ} \mathrm{C}$. LWT-Food Science and Technology., 91, 484-490.

Farvin, K. H. S., \& Surendraraj, A. (2019). Plant antioxidant extracts: effect on lipid or protein oxidation in seafood products. Encyclopedia of Food Chemistry, 609-620.

Kuepethkaew, S., Sangkharak, K., Benjakul, S., \& Klomklao, S. (2017). Use of TPP and ATPS for partitioning and recovery of lipase from Pacific white shrimp (Litopenaeus vannamei) hepatopancreas. Journal of Food Science and Technology., 54(12), 3880-3891.

Li, H. Y., Zhao, Q., \& Liu, H. M. (2016). Study on application and antioxidation activity of tea polyphenols to baked catfish. Food Research And Development., 37(24), 180-183.

Li, J. K., Hui, T., Wang, F. L., Li, S., Cui, B. W., Cui, Y. Q., \& Peng, Z. Q. (2015). Chinese red pepper (Zanthoxylum bungeanum Maxim.) leaf extract as natural antioxidants in salted silver carp (Hypophthalmichthys molitrix) in dorsal and ventral muscles during processing. Food Control., 56, 9-17.

Li, Y. P., \& Huan, Y. J. (2017). The rules of lipid oxidation in subcutaneous and intramuscular of dry-cured goose during processing. Science and Technology of Food Industry., 4, 101-105.

Mesquita, C. S., Oliveira, R., Bento, F., Geraldo, D., Rodrigues, J. V., \& Marcos, J. C. (2014). Simplified 2,4-dinitrophenylhydrazine spectrophotometric assay for quantification of carbonyls in oxidized proteins. Analytical Biochemistry., 458(1), 69-71. 
Mi, H.-b., Guo, X., \& Li, J.-r. (2016). Effect of 6-gingerol as natural antioxidant on the lipid oxidation in red drum fillets during refrigerated storage. LWT-Food Science and Technology., 74, 70-76.

Miranda, J. M., Trigo, M., Barros-Velázquez, J., \& Aubourg, S. P. (2018). Quality enhancement of chilled lean fish by previous active dipping in Bifurcaria bifurcata alga extract. Food and Bioprocess Technology., 11(9), 1662-1673.

Nie, X., Wang, L., \& Wang, Q. (2018). Effect of a sodium alginate coating infused with tea polyphenols on the quality of fresh Japanese sea bass (Lateolabrax japonicas) fillets. Journal of Food Science., 83(6), 1695-1700.

Otero, L., Pérez-Mateos, M., \& López-Caballero, M. E. (2017). Hyperbaric cold storage versus conventional refrigeration for extending the shelf-life of hake loins. Innovative Food Science \& Emerging Technologies., 41, 19-25.

Özyurt, G., Kuley, E., Balikçi, E., Kaçar, C.., Gökdogan, S., Etyemez, M., \& Özogul, F. (2012). Effect of the icing with rosemary extract on the oxidative stability and biogenic amine formation in sardine (Sardinella aurita) during chilled storage. Food and Bioprocess Technology., 5(7), 2777-2786.

Park, J. W. (1995). Surimi gel colors as affected by moisture content and physical conditions. Journal of Food Science., 60(1), 15-18.

Qiu, X. J., Chen, S. J., \& Dong, S. Y. (2014). Effects of silver carp antioxidant peptide on the lipid oxidation of Sierra fish fillets (Scomberomorus Niphonius) during frozen storage. Journal of food biochemistry., 38(2), 167-174.

Sae-leaw, T., \& Benjakul, S. (2014). Fatty acid composition, lipid oxidation, and fishy odour development in seabass ( $\mathrm{r}$, Lates calcarifer $\mathrm{r}$, ) skin during iced storage. European Journal of Lipid Science and Technology., 116(7), 885-894.

Sasakia, K., Alameda, J., Weissa, J., Villeneuveb, P., \& Giraldo, L. J. L. (2010). Relationship between the physical properties of chlorogenic acid esters and their ability to inhibit lipid oxidation in oil-in-water emulsions. Food Chemistry., 118(3), 830-835.

Turguta, S. S., Ișıkçıb, F., \& Soyerc, A. (2017). Antioxidant activity of pomegranate peel extract on lipid and protein oxidation in beef meatballs during frozen storage. Meat Science, 129, 111-119.

Sheard, P. R., Enser, M., Wood, J. D., Nute, G. R., Gill, B. P., \& Richardson, R. I. (2000). Shelf life and quality of pork and pork products with raised n-3 PUFA. Meat science., 55(2), 213-221.

Smichi, N., Gargouri, Y., Miled, N., \& Fendri, A. (2013). A grey mullet enzyme displaying both lipase and phospholipase activities
Purification and characterization. International Journal of Biological Macromolecules., 58, 87-94.

Srinivasan, S., Xiong, Y., \& Decker, E. A. (1996). Inhibition of protein and lipid oxidation in beef heart Surimi-like material by antioxidants and combinations of $\mathrm{pH}, \mathrm{NaCl}$, and buffer type in the washing Mediar. Journal of Agricultural and Food Chemistry., 44(1), 119125.

Sun, X. Y., Guo, X. B., Ji, M. Y., Wu, J. J., Zhu, W. J., Wang, J. H., Cheng, C., Chen, L., \& QQ. Z. (2019). Preservative effects of fish gelatin coating enriched with $C U R / \beta C D$ emulsion on grass carp (Ctenopharyngodon idellus) fillets during storage at $4^{\circ} \mathrm{C}$. Food Chemistry, 2019(272), 643-652.

Wu, C. H., Fu, S. L., Xiang, Y. C., Yuan, C. H., Hu, Y. Q., Chen, S. G., Liu, D. H., \& Ye, X. Q. (2016). Effect of chitosan gallate coating on the quality maintenance of refrigerated $\left(4{ }^{\circ} \mathrm{C}\right)$ silver Pomfret (Pampus argentus). Food and Bioprocess Technology., 9(11), $1835-1843$.

Wu, J. M., Chen, H. X., \& Li, H. (2016). Antidepressant potential of chlorogenic acid-enriched extract from eucommia ulmoides oliver bark with neuron protection and promotion of serotonin release through enhancing synapsin i expression. Molecules., 21(3), 260.

Xiang, Z. N., \& Ning, Z. X. (2008). Scavenging and antioxidant properties of compound derived from chlorogenic acid in South-China honeysuckle. LWT - Food Science and Technology., 41(7), 11891203.

Xiong, G. Y., Gao, X. Q., Wang, P., Xu, X. L., \& Zhou, G. H. (2016). Comparative study of extraction efficiency and composition of protein recovered from chicken liver by acid-alkaline treatment. Process Biochemistry., 51, 1629-1635.

Zakaria, N. A., \& Sarbon, N. M. (2018). Physicochemical properties and oxidative stability of fish emulsion sausage as influenced by snakehead ( Channa striata ) protein hydrolysate. $L W T$ - Food Science and Technology., 94, 13-19.

Zhao, D., Li, Z., Yang, J., \& Chen, Y. (2009). A method for determination of acid value in aquatic products. South China Fisheries Science., $5(5), 72-74$.

Zhou, X., Zhou, D.-Y., Liu, Z.-Y., Yin, F.-W., Liu, Z.-Q., Li, D.-Y., \& Shahidic, F. (2019). Hydrolysis and oxidation of lipids in mussel Mytilus edulis during cold storage. Food Chemistry., 272, 109-116.

Publisher's note Springer Nature remains neutral with regard to jurisdictional claims in published maps and institutional affiliations. 